\title{
Tingkat Herbivori Daun Mangrove Rhizopora mucronata dan Rhizophora apiculata Hasil Replantasi di Ujung Piring, Kabupaten Jepara
}

\author{
Nur Cahyo Widianto*, Rudhi Pribadi, Ibnu Pratikto \\ Departemen IImu Kelautan, Fakultas Perikanan dan IImu Kelautan, Universitas Diponegoro \\ Jl. Prof. H. Soedarto S.H, Tembalang,Semarang, Jawa Tengah 50275 Indonesia \\ ${ }^{*}$ Corresponding author, e-mail: nwidi265@yahoo.com
}

\begin{abstract}
ABSTRAK : Tujuan dari penelitian ini untuk mengetahui tingkat herbivori R. apiculata dan $R$. mucronata, dan ketinggian pohon serta umur daun di vegetasi mangrove Di daerah Ujung Piring, Kabupaten Jepara. Metode yang digunakan dalam penelitian ini adalah metode deskriptif yaitu metode pencari fakta dengan interpretasi secara tepat, penentuan lokasi pengambilan sampel dilakukan dengan metode purposive sampling. Sampel daun mangrove dari spesies R. apiculata dan $R$. mucronata diambil dari tiga kategori ketinggian yang berbeda yaitu $<1 \mathrm{~m}$ dan $>1-3 \mathrm{~m}$, masing-masing sebanyak 10 ulangan (pohon) untuk setiap kategori. Daun dipisahkan berdasarkan umur daun (tua atau muda) serta kondisi daun (utuh atau rusak) total daun diambil sebanyak $10 \%$. Hasil penelitian menunjukan nilai rerata tingkat herbivori R. apiculata yaitu $4,66 \%$ kisaran $(0,16 \%$ $8,93 \%)$ sampai dengan $11,59 \%$ kisaran $(2,14-21,97 \%)$ sedangkan pada R. mucronata yaitu $5,23 \%$ kisaran $(0,31-9,94 \%)$ sampai dengan $11,37 \%$ kisaran $(2,56-17,91 \%)$. Berdasarkan uji statistik dapat disimpulkan bahwa faktor spesies, ketinggian dan umur daun berpengaruh nyata terhadap tingkat herbivori pada kedua spesies R. apiculata dan R. mucronata yaitu: $(P<0,05)$.
\end{abstract}

Kata kunci : Herbivori, R. mucronata, R. apiculata

\section{The Level of Herbivory Mangrove Leaves Rhizopora mucronata and Rhizophora apiculata Replantation Results in Ujung Piring, Jepara Regency}

ABSTRACT : The purpose of this research is to know the herbivory level of $R$. apiculata and R. mucronata, the tree height and the age of the leaves in mangrove vegetation Dusun Ujung Piring, Jepara District. The method used in this research is descriptive method and that means fact finding method with the correct interpretation, in determining the location of the sampling is done by purposive sampling method. Samples of mangrove leaves from the $R$. apiculata and $R$. mucronata species were taken from three different height categories: $<1 \mathrm{~m}$ and $>1-3$, each of 10 replicates (trees) for each category. Leaves are separated by the age of the leaves (old or young) and leaf condition (whole or damaged) leaves in total are taken as much as $10 \%$. The results showed that the average value of herbivory level of $R$. apiculata was $4,66 \%(0,16-8,93 \%)$ up to $11,59 \%(2,14-$ $21,97 \%)$ while in $R$. mucronata $5,23 \%(0,31-9,94 \%)$ up to $11,37 \%(2,56-17,91 \%)$. Based on statistical test it can be concluded that species factor, height and leaf age have a real impact on the herbivory level on $R$. apiculata and $R$. mucronata.

Keywords : Herbivory, R. mucronata, R. apiculata

\section{PENDAHULUAN}

Mangrove mempunyai peran yang sangat penting baik secara ekologi, biologi, sosial ekonomi dan jasa.Mangrove banyak menyumbang bahan-bahan organic bagi perairan disekitarnya dan bahanbahan ini dimanfaatkan oleh organisme yang hidup didalam perairan tersebut contohnya ikan, udang, kepiting. Bahanbahan organik ini berasal dari serasah mangrove dan yang paling banyak menyumbang adalah daun mangrove dibandingkan bagian lain.

Pemangsaan (herbivori) adalah memakan seluruh atau sebagian jaringan tumbuhan oleh konsumen (pemangsa). Menurut Crawley (1983) herbivora adalah binatang yang memakan jaringan tumbuhan, antara lain detrivor, jamur, virus, serangga sebagai pemangsa daun (phytopagus), pemakan akar, parasit tumbuhan, pemakan benih (granivorous) serta hewan 
pemakan bunga dan buah. Mangrove juga mengalami pemangsaan baik itu pada daun, prolpagul (buah) seperti tumbuhan lain.

Pemangsaan secara langsung mempengaruhi laju pertumbuhan tanaman karena berkurangnya daerah fotosintesis (pemangsaan helaian daun), perubahan keseimbangan karbohidrat (pengisapan cairan dari daging buah), gangguan transport nutrien dan air (pemangsaan akar) dan melemahnya struktur fisik tumbuhan (Crawley, 1983). Menurut beberapa peneliti bahwa pemangsaan dapat berpengaruh terhadap tingkat individu dan komunitas, membawa perubahan komposisi kimia pada tumbuhan, kualitas dan kuantitas serasah, produktivitas dan reproduksi serta menjadi penyebab penggundulan mangrove (Belsky,1986; Choudhury, 1988.

Pemangsaan dapat menyebabkan penurunan produktivitas perairan karena berkurangnya sumbangan bahan organik dari tumbuhan mangrove. Kondisi ini sesuai hasil penelitian Framsworth dan Ellison (1996) yaitu terjadi pengurangan produksi primer bersih sebesar $5-20 \%$ pada perairan laut akibat pemangsaan terhadap daun mangrove.

\section{MATERI DAN METODE}

Materi penelitian ini adalah daun $R$. apiculata dan $R$. mucronata yang terdapat di vegetasi mangrove di Ujung Piring, Jepara. Penentuan lokasi pengambilan sampel menggunakan purposive sampling method yaitu metode yang selektif dengan mempertimbangkan tujuan dari didapatkanya parameter penelitian tersebut.

Penentuan lokasi pada penelitian ini dengan memperhatikan vegetasi mangrove yang diduga mengalami herbivori dengan pertimbangan peneliti dapat mengamati keberadaan dari spesies dominan sesuai kriteria seperti ketinggian dan umur pohon. Adapu lokasi penelitian dapat dilihat pada Gambar 1. Menurut Pribadi (1998) pengambilan sampel daun muda dekat dengan ujung dahan, berwarna hijau terang, lunak sedangkan daun tua lebih jauh dari ujung dahan, berwarna gelap dan lebih kasar. Kurniawan et al., (2011) mengatakan sampel foto daun yang diolah menggunakan aplikasi Image-J harus sesuai dengan format RGB yaitu 8 bit dengan menggunakan ketentuan straight. Pengukuran pada gambar daun dilakukan dengan open folder pada toolbar. Klik Image > Type > 8-bit. Pada Image-J untuk analisis herbivori bagian background disebut sebagai segmentasi gambar untuk melihat besaran herbivori pada daun. Analisis dilakukan dengan dipilih Image > Adjust > Threshold. Level Threshold diatur untuk mengetahui tingkat kecerahan pada gambar.

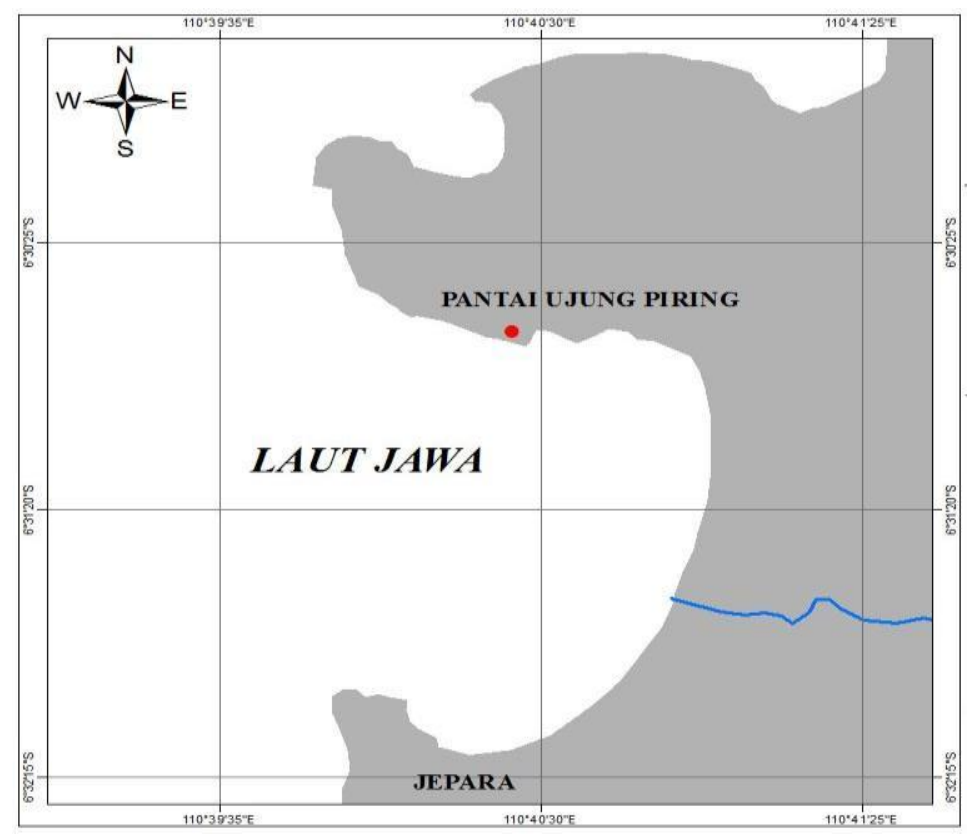

Gambar 1. Lokasi Penelitian di Pantai Ujung Piring, Jepara 


\section{HASIL DAN PEMBAHASAN}

Total pengambilan daun keseluruhan berjumlah 1.535, terdiri dari daun $R$. apiculata sebanyak 912 dan daun $R$. mucronata sebanyak 623. Pengambilan dilakukan dengan membedakan ketinggian pohon dan umur daun. Rekapitulasi kondisi daun yang diambil antar spesies disajikan pada Table 1 dan 2. Total jumlah daun di lokasi sampling sebanyak 1.535 yang terdiri dari daun $R$. apiculata sebanyak 912 dan daun $R$. mucronata sebanyak 623 . Berdasarkan umur, jumlah daun R. apiculata muda sebanyak 433 dan daun tua sebanyak 479 (Tabel 3).

Hasil menunjukan perbedaan spesies berpengaruh terhadap persentase. Hasil perhitungan rerata pengaruh spesies menunjukan bahwa spesies berpengaruh terhadap tingkat herbivori (Tabel 3). Spesies $R$. apiculata \% tingkat herbivori terendah 4,66\% (kisaran 0,16\%- 8,93\%) dan tertinggi $11,59 \%$ (kisaran 2,14\% -21,97\%) sedangkan R. mucronata \% terendah 5,23\% (kisaran $0,31 \%-19,75 \%$ ) dan tertinggi $11,37 \%$ (kisaran 2,56\% -17,91\%). Hal ini diduga kepadatan vegetasi memberikan pengaruh pada tingginya tingkat herbivori. $R$. apiculata pada vegetasi mangrove yang ditemukan mengelompok dibandingkan $R$. mucronata. Pengaruh tersebut sesuai dengan kondisi di lapangan bahwa kepadatan vegetasi $R$. apiculata lebih besar dibandingkan $R$, mucronata. Semakin tinggi kepadatan vegetasi maka menyebabkan serangga dapat memilih lebih banyak pohon lainnya.Tingkat herbivori pada kedua spesies tersebut. Rerata tingkat herbivori tertinggi $R$. apiculata yaitu pada daun tua dengan Kelas ketinggian $>1-3 \mathrm{~m}$ sebesar 9,15\% (kisaran 2,03\%-18,29\%) dan terendah yaitu pada daun muda Kelas ketinggian $<1 \mathrm{~m}$ sebesar 4,66 $\%$ (kisaran 0,16\%-8,93\%). Rerata tingkat herbivori tertinggi $R$. mucronata yaitu pada daun tua dengan Ketinggian $>1-3$ m sebesar 11,37 \% (kisaran 2,56-17,91\%) dan terendah yaitu pada daun muda Ketinggian $<1$ m sebesar 5,23 \% (kisaran 0,31-9,94\%).

Secara umum kelas kerusakan pada kedua spesies yang didapatkan pada hasil diatas termasuk pada Kelas I $(<4,00 \%)$ dan Kelas II (>4,01\%- 8,00\%). Luasan daun yang dimangsa tergolong rendah hal ini diduga berpengaruh pada produktivitas primer mangrove dan perairan. Farnsworth Ellison (1996), produktivitas primer terjadi pengurangan sebesar $5-20 \%$ di perairan akibat herbivori daun mangrove. Feller (1995), hilangnya jaringan akibat herbivori berdampak

Tabel 1. Total Jumlah Daun dan Persentase Daun R. apiculata Kondisi Utuh dan Rusak

\begin{tabular}{ccccr}
\hline Ketinggian $(\mathrm{m})$ & Umur Daun & Kondisi Daun & $\mathrm{n}$ & $\%$ \\
\hline$<1$ & Muda & Utuh & 51 & 54,84 \\
& & Rusak & 42 & 45,16 \\
& Tua & Utuh & 37 & 53,62 \\
& & Rusak & 32 & 46,38 \\
& Muda & Utuh & 193 & 50 \\
& & Rusak & 193 & 50 \\
& Tua & Utuh & 182 & 50 \\
& & Rusak & 182 & 50 \\
\hline
\end{tabular}

Tabel 2. Total Jumlah Daun dan Persentase Daun R. mucronata Kondisi Utuh dan Rusak

\begin{tabular}{ccccc}
\hline Ketinggian $(\mathrm{m})$ & Umur Daun & Kondisi Daun & $\mathrm{n}$ & $\%$ \\
\hline$<1$ & Muda & Utuh & 27 & 47,37 \\
& & Rusak & 30 & 52,63 \\
& Tua & Utuh & 25 & 47,17 \\
& & Rusak & 28 & 52,83 \\
& Muda & Utuh & 132 & 49,62 \\
& & Rusak & 134 & 50,38 \\
& \multirow{2}{*}{ Tua } & Utuh & 123 & 49,80 \\
& & Rusak & 124 & 50,20 \\
\hline
\end{tabular}


Tabel 3. Rerata Tingkat Persentase Kerusakan Daun (muda, tua) jenis $R$. apiculata dan $R$. mucronata pada Ketinggian yang Berbeda.

\begin{tabular}{rcccc}
\hline \multirow{2}{*}{$\begin{array}{c}\text { Ketinggian } \\
(\mathrm{m})\end{array}$} & Muda & Kisaran & Tua & Kisaran \\
\hline R. apiculata & & & & \\
& & & & \\
$>1$ & 4,66 & $(0,16-8,93)$ & 5,07 & $(1,27-9,30)$ \\
R. mucronata & 8,35 & $(1,56-17,80)$ & 9,15 & $(2,03-18,29)$ \\
& & & & \\
$>1$ & 5,23 & $(0,31-9,94)$ & 5,94 & $(1,63-8,70)$ \\
$>1-3$ & 10,09 & $(1,85-19,75)$ & 11,37 & $(2,56-17,91)$ \\
\hline
\end{tabular}

buruk terhadap pertumbuhan karena fungsi daun sebagai tempat fotosintesis yang mampu menghasilkan bahan organik akan terganggu. Fotosintesis terjadi akibat adanya perubahan energi kimia dan senyawa karbon menjadi bahan organik dengan bantuan sinar matahari.

Hasil perhitungan rerata pengaruh umur daun terhadap tingkat herbivori menunjukan kerusakan tertinggi pada kedua spesies. Hasil pada daun tua dengan rerata spesies $R$. apiculata $9,15 \%$ dan $R$. mucronata $11,37 \%$ lebih besar dibandingkan rata-rata daun muda spesies $R$. apiculata 8,35 dan $R$. mucronata $11,37 \%$. (Askornkoae et al., 1991), penyebab tingginya tingkat herbivori pada daun tua karena daun muda lebih disukai herbivora yang biasanya menyerang sejak daun dalam kondisi kuncup atau muda, sehingga ketika daun mengalami fase tua luasan yang rusak semakin besar karena ukuran yang bertambah. Soenardjo (2013), daun Rhizophora tua mengalami pemangsaan paling tinggi dibandingkan dengan daun muda.

Hal ini, didukung dengan kandungan nitrogen yang tinggi pada daun tua. Kondisi tersebut menarik perhatian herbivora untuk mengkonsumsi daun tua. Berbeda halnya dengan hasil penelitian Septyaningsih (2015), herbivori tertinggi terjadi pada daun muda dibandingkan dengan daun tua, diduga daun muda lebih menarik herbivora dibandingkan daun tua. Aide (1993), herbivori pada daun muda lebih tinggi dibandingkan daun tua karena diduga kandungan serat rendah dan lunak untuk dikonsumsi, sehingga disukai herbivora. Kandungan tanin pada daun muda lebih rendah dibandingkan daun tua yang berfungsi melindungi jaringan daun dari herbivora dan mencegah kebusukan. Farnsworth \& Ellison (1993), kualitas nutrisi memperlihatkan penurunan pada daun tua. Palatability daun diduga juga berpengaruh terhadap tingkat herbivori. Daun muda terletak lebih terbuka dibanding daun tua sehingga lebih banyak terkena sinar matahari. Berdasarkan sifat sensitifnya terhadap sinar matahari maka daun yang mendapatkan cahaya matahari akan menghasilkan produk fotosintesis yang lebih tinggi.

Tingginya pohon memberikan pengaruh yang signifikan. Semakin tinggi pohon maka kerusakan daun lebih besar. Lowman (1983), ketinggian memberikan perbedaan diduga oleh faktor cahaya matahari. Biomassa daun yang lebih besar terdapat pada pohon yang terkena cahaya matahari dibandingkan pohon lainnya. Hal ini diasumsikan bahwa daun ketinggian $>1-3 \mathrm{~m}$ menerima cahaya matahari lebih banyak dibandingkan Ketinggian rendah $<1 \mathrm{~m}$ mendapatkan energi. Kandungan hasil fotosintesis biasanya lebih tinggi dan mampu menarik perhatian dari herbivora yang ada dilokasi. Kerusakan daun pada ketinggian $<1 \mathrm{~m}$ disebabkan oleh serangga, gastropod dan kepiting.

Lowman (1984), serangga memilih memakan daun pada ketinggian $<1 \mathrm{~m}$ karena hidup dekat dengan permukaan tanah yang memiliki kelembapan tinggi. Ketinggian $>1-3 \mathrm{~m}$ kerusakan dapat disebabkan oleh sinar matahari yang menyebabkan daun menjadi rusak. Hal ini berbanding terbalik pada penelitian Newberry \& Foresta (1985), bahwa daun pada ketinggian $>1-3 \mathrm{~m}$ akan mengalami herbivori yang rendah. Daun yang terkena sinar matahari kandungan taninnya lebih tinggi dibandingkan daun yang ternaungi. kondisi tersebut diakibatkan adanya pengaruh penggenangan yang disebabkan proses pasang surut pada mangrove. Daun yang terendam pada saat surut menyebabkan spesies di perairan dapat mengkonsumsi daun pada ketinggian $>1-3 \mathrm{~m}$, selain itu penggenangan diduga merubah kondisi fisik dan kandungan kimia. 


\section{KESIMPULAN}

Rerata tingkat herbivori $R$. apiculata yaitu $4,66 \%$ sampai dengan $11,59 \%$ sedangkan pada $R$. mucronata yaitu $5,23 \%$ sampai dengan $11,37 \%$. Ketinggian pohon dan umur daun berpengaruh terhadap herbivori $R$. apiculate dan $R$. mucronata $(\mathrm{P}<0.05)$.

\section{DAFTAR PUSTAKA}

Aide, T.M. 1993. Pattern of Leaf Development and Herbivory in a Tropical Understory Community. Ecological Society of America. Ecology, 74 (2): 455-566.

Askornkoae, S. 1991. Ecology and Management of Mangrove. IUCN.Bangkok.

Belsky, J. 1986. Infant Day Care: A Cause for Concern. Zero to Three, 6:1-7.

Chaudhuri, A.B. and Choudhury, A., 1994. Mangroves of the Sundarbans. Volume 1: India. International Union for Conservation of Nature and Natural Resources (IUCN). 2479 pp.

Crawley, M.J. 1983: Herbirory: The Dynamics of Animal-Plant Interactions. Studies in Ecology Volume 10.Oxford: Blackwell Scientific Publications

Ellison, A.M. \& Farnsworth, E.J., 1996. Anthropogenic disturbance of Caribbean mangrove ecosystems: past impacts, present trends, and future predictions. Biotropica, pp.549-565.

Kurniawan, C., Waluyo, T.B. and Sebayang, P., 2011. Analisis Ukuran Partikel Menggunakan Free Software ImageJ. In Prosiding Seminar Nasional Fisika. Pusat Penelitian Fisika-Lipi Serpong, 12-13 Juli 2011.

Lowman, M.D. 1983. An Assessment of techniques for measuring herbivory: is rainforest defoliation more intense than we thought. Biotropica. 16(4):264-268.

Lowman.M.D.1984. An Assesment of Techniques for Measuring Herbivory: is Rainforest Defoliation More Intense Then we Thought. Biotropica 16(4):264-268

Pribadi R. 1998. The ecology of mangrove vegetation in Bintuni Bay, Irian Jaya, Indonesia. Departemen of Biological and Molecular Sciences University of Stirling-Scotland.

Septyaningsih. Erma, Ardli E.R, Widyastuti Ani. 2015. Studi Morfometri dan Tingkat Herbivori Daun Mangrove Di Segara Anakan Cilacap. Scripta Biologica. 1(2):137-140

Soenardjo, N., Pemangsaan daun Rhizophora stylosa Griff dan Avicennia marina (Forsk) Vierh. Buletin Oseanografi Marina, 2(2):41-47 